\title{
sciendo
}

DOI 10.2478/sbe-2019-0042

SBE no. 14(3) 2019

\section{CONVENTIONAL THEORY'S RELEVANCE: EVIDENCE FROM JAPAN}

\author{
BURNETE SORIN \\ Lucian Blaga University of Sibiu, Romania
}

\begin{abstract}
:
The formidable surge in the volume of international trade after 1960 stimulated surveys designed to ascertain to what degree the commercial flows among nations reflected the structure of their economies, in other words, how tight was the correlation between international exchanges and the specific attributes of participating nations. In fact, scholars were keen to test the relevance of the conventional Heckscher-Ohlin theory, that is, to what extent did nations' exports reflect their endowment with factors of production, more specifically, whether their exports used their abundant factors intensively. I try to show that, although most of the tests reached their purpose in that they confirmed the conventional theory's predictions, in certain cases such as Japan, whose economy is arguably idiosyncratic, factor specificity is more relevant than factor intensity in explaining, not only the country's international specialization but also the premises of its uncanny $20^{\text {th }}$ century ascendance to the top of the world economy.
\end{abstract}

Key words: Factor proportion, factor specificity, factor intensity, labor mobility, real wage

\section{Fevered testing in the wake of Leontief's paradox}

The emergence of Heckscher-Ohlin's factor proportion theorem and its corollaries, Samuelson' factor price equalization theorem respectively the theorem of relative prices of goods and relative real returns of factors of production by Stolper and Samuelson, but most of all the puzzling results of Leontief's tests aka Leontief's paradox, sparked a testing fever among the economists, eager to ascertain the relevance of the mentioned theorems (mostly known as components of the conventional theory), that is whether imports and exports could really compensate structural differences among national economies. Hufbauer (1970) performed and ample test based on the data regarding international trade and economic structure of a group of 24 countries accounting for about 90 percent of the then non-socialist countries' exports of manufactured goods. The results, of which the author himself was nevertheless somewhat disappointed for not being enough clear cut, were still eloquent: on the one hand, there are tight correlations among goods' qualities (wages vs. skills, physical capital vs. human capital, economies of scale vs. sophisticated goods etc.); on the other hand, bilateral correlations between goods' qualities incorporated 
in the analyzed countries' exports structures, are significant (an average value of 0.683). ${ }^{1}$ In a nutshell, the results indicate with enough clarity that the structure of world exports exerts "an intriguing kind of selectivity", the goods whose characteristics are consistent with export countries' economic structure being most heavily promoted. Thus, "the composite trading pattern" is in accord with theory predictions, concludes Hufbauer.

Bela Balassa was equally preoccupied by the impact of technology and human capital upon the structure of international trade flows, his research work being materialized in several surveys carried out and published after 1970. The apex was reached by a study published in 1986, based on data about exports of 38 countries in 1971, including 167 categories of manufactured goods. The importance of the mentioned study is given by its all-encompassing tendency, the objective being "to test the Heckscher-Ohlin theory by simultaneously introducing trade flows, factor intensities, and factor endowments in an empirical investigation of the pattern of comparative advantage in manufactured goods in a multi-country model." The procedure implies aggregating the two forms of capital (physical and human), which in Balassa's view, allow the testing of an important hypothesis that had been ignored by both the founders of the factor proportion theory and Leontief himself, that is: the two forms of capital are either perfectly complementary or perfectly substitutable. (Balassa, 1986)

If countries do tend to export the goods whose characteristics are consistent with their economic structure, as stated earlier, the factor proportion theory might still break down owing to two main causes: the specificity of factors of production respectively the possibility of factor intensity reversals. The factor specificity notion (Jones, 1971) claims that certain factors of production, for example capital, land etc., aside from being abundant or scarce, may be sector-specific, that is, they may be immobile between sectors and used only in the production of a specific good. Other factors, for example labor, may be deemed perfectly mobile. These assumptions, without being entirely realistic, are still more plausible than factors' full mobility among sectors, as postulated by the factor proportion theorem.

As for the reversal of factor intensity, it is likely to take place if the difference in the elasticity of substitution of one factor to another in the production of goods is high enough. (Minhas, 1962) If, for example, wage rates rise relative to capital costs, industries with relatively higher elasticity of substitution between capital and labor become relatively more capital intensive than the ones with the lower elasticity of substitution regardless of factor intensity. Minhas's test reveals that, for instance, the US paper industry is more capitalintensive than the dairy-products industry at all values of wage/rental $(\mathrm{w} / \mathrm{r})$ greater than $\$ 2,136$, while it is relatively labor-intensive for all smaller values of the ratio. Thus, concludes Minhas, $\$ 2,136$ is the critical value of $w / r$ at which the switch in relative capitalintensity occurs. In conclusion, factor endowment is indeed a source of comparative advantage, yet assumptions such as the impossibility of factor intensity reversals, or that all factors are perfectly mobile between sectors, are hardly realistic.

In view of the aspects highlighted earlier, the case most fit, either to evidence or to refute the conventional theory' $s$ predictions is probably Japan's, whose economy underwent a spectacular hundred-year development period, between the late 1860s and the late 1960s, consisting of two distinct stages: an early formidable expansion during the 
Meiji era (1868-1912) ${ }^{2}$ triggered by the country's openness to international trade, followed by a no less impressive expansion in the aftermath of WW II, when the country was also deeply anchored in international trade. Japan started from the export of petty things like silk-warms and silk-cocoons in the $19^{\text {th }}$ century only to become, one hundred years later, the world's number one exporter, not only of automobiles and electronic products - which flooded western markets in the 1980s - but equally of highly sophisticated manufactured goods $^{3}$. This evolution points to a linear trend toward specialization in capital and knowledge intensive goods and away from labor intensive ones.

In the rest of the paper, I shall try to demonstrate that, despite its unquestionable continuity, Japan's hundred-year process of integration into and then domination of international trade cannot be explained by a sole type of economic modeling. For all their similarity in terms of development pattern and specialization trends, the two subperiods referred to earlier accommodate differently to the convention theory's canons. I shall try to emphasize the complementarity of, rather than contradiction between the two pillars of the conventional theory, the Stolper-Samuelson theorem respectively the specific factors model. In chapter II, I shall try to test the relevance of the former on Japan's early development era, with the aid of Edgeworth's production box model. ${ }^{4}$ In chapter III, I shall try to prove that the early $19^{\text {th }}$ century expansion of Japan's economy can hardly be explained unless one considers the specificity of factors of production. Therefore, I believe the specific factors model is a more adequate tool for that purpose. ${ }^{5}$ Finally, in chapter IV, I shall try to prove that factor endowment is more relevant to explain the post WW II period than factor specificity, for two main reasons: first, Japanese exports exhibit pronounced duality in terms of destination: capital intensive goods were mostly sold to developing countries, whereas exports bound to western countries were preponderantly labor intensive. (Heller, 1976) Second, since the agricultural sector found ever harder to compete with imported products due to Japan's low productivity agriculture as compared to other countries in the region and beyond, it has been intensively protected by all Japanese governments. Therefore, the agricultural sector's contribution to Japan's contemporary development is virtually insignificant and so is its specific factor, the land. Briefly, if the land factor is ignored, factors specificity is less relevant than in the early $19^{\text {th }}$ century period.

\section{Japan's early development era: more sense with factor specificity}

Economists undertook direct testing of the Stolper-Samuelson (S-S) theorem on the Japanese economy in the aftermath of the Meiji restauration. Although in the pre-trade period the Japanese economy had been competitive enough (Harrigan, 2003), according to Bernhofen, Brown and Masuyaki (2012), Japan's exit from autarchy and involvement in international trade further raised its competitiveness through the improvement of its terms of trade. At the end of the $19^{\text {th }}$ century, the cited authors show, the Japanese export industries (silk, silk-warms, cocoons, tea, copper etc.) were concentrated in the eastern part of the archipelago (the Kanto region), while industries producing importable goods (rice, cotton, sugar etc.) were in the west (the Kinai region). The cited authors argue that Japan under Meiji rule offers a natural experiment of the S-S theorem, confirming the latter's predictions, yet with an observation: the upward impact upon exports' prices proved 
stronger than the downward trend in import-competing industries; the latter turned out to be resilient enough.

Presumably, by the time Japan's economy opened to world markets capital was scarce, so that producers in the Kanto region, hereafter called Kanto, and the Kinai region, hereafter called Kinai used two factors of production, labor and land. Suppose the goods produced in Kanto (hereafter called Kanto goods) were labor intensive, while the goods produced in Kinai (hereafter called Kinai goods) were land intensive. In figure 1 (appendix 1 ), which represents Japan's production box, initial equilibrium is in point $B$ on the contract curve $\mathrm{O}_{K a} \mathrm{O}_{K i}$.

According to the S-S theorem, if both factors are mobile between sectors and presuming technologies and factors supply unchanged, the effect of a change in the relative price of goods on the relative price of factors of production depends on factor intensity, namely the proportion in which factors are used in the production of either good. Changes in the price of goods traded internationally, the theory goes, triggers changes in the price of factors of production in favor of the factor used intensively in the production of the good whose price has risen. (Stolper, Samuelson, 1941) To see whether the Japanese economy positively responds to the theorem, suppose that under perfect competition and constant returns to scale, the nominal wage rate is equal to the value of the marginal product of labor and the nominal rental rate is equal to the value of the marginal product of land, which mathematically can be expressed as follows:

$$
\begin{aligned}
& p_{K a} M P_{l}^{K a}=w \text { and } p_{K a} M P_{T}^{K a}=R \\
& p_{K i} M P_{l}^{K i}=w \text { and } p_{K i} M P_{T}^{K i}=R
\end{aligned}
$$

where:

$M P_{T}^{K a}, M P_{T}^{K i}=$ the marginal physical product of land in Kanto respectively Kinai;

$M P_{l}^{K a}, M P_{l}^{K i}=$ the marginal physical product of labor in Kanto respectively Kinai;

$w=$ marginal revenue product of labor;

$p_{K a}, p_{K i}=$ the price of Kanto goods and Kinai goods respectively.

The wage rate is equal in both sectors due to factor's perfect mobility between sectors and markets' competitiveness. Equations (1) and (2) can be rewritten as follows:

$w / p_{K a}=M P_{l}^{K a}$ and $w / p_{K i}=M P_{l}^{K i}$

$R / p_{K a}=M P_{T}^{K a}$ and $R / p_{K i}=M P_{T}^{K i}$

Equations (3) and (4) indicate that the factors' real income depends on their marginal physical product. If the price of Kanto goods rises following Japan's openness to international trade, the relative price of labor (the factor used intensively in the production of Kanto goods) rises. Consequently, both sectors will use less labor (now relatively more expensive) and more land (now relatively cheaper). In figure 1 (appendix 1), this is illustrated by the shift of equilibrium from point $B$ to point $A$, on Japan's contract curve. In $A$, following a rise in the relative price of labor $(w / R)$, both sectors will use less labor and more land than in $B$ ( $\lambda_{K i}$ is flatter than $\lambda_{K a}$ and $\mu_{K a}$ is flatter than $\left.\mu_{K i}\right)$. The decline in the labor-land ratio will lead, because of the decreasing returns law, to a rise in the marginal physical product of labor and a fall in the marginal physical product of land in both sectors. As a result, the real wage rises in terms of both goods, while the real rental rate falls, also in terms of both goods, as can be inferred from equations (1) and (2), thereby confirming the S-S theorem's predictions. 


\section{The post-WW II era: factor specificity once again}

In chapter II, I tested the power the S-S theorem to set the directions of Japan's international specialization following the country's openness to international trade during the Meiji era. Since the labor-intensive Kanto goods could be sold on foreign markets at higher prices than the ones that prevailed in autarchy, real wages rose. Concomitantly, the price and real income of land, the factor used intensively in the production of importable goods, dropped. Thus, the effects of foreign competition set the directions of Japan's future specialization in accordance with the S-S theorem: it would specialize in and export labor intensive Kanto goods. Yet the results are not fully conclusive because considering Kanto as labor intensive is an oversimplifying assumption. As-a-matter-of-fact, the Kanto goods production used an additional factor input beside labor, namely human capital, implying specialized knowledge and skills. The situation therefore visibly deviates from the basic $2 \times 2 \times 2$ factor proportion model in that there are three factors of production instead of two: the Kanto goods used human capital and labor, while the Kinai goods used land and labor. In terms of Jones' model, human capital $(H)$ is a specific factor to Kanto goods production, being exclusively employed in the respective sector, while land $(T)$ is specific to the Kinai goods sector and used exclusively therein. Human capital and land are in fixed amounts and immobile between sectors, while labor $(L)$ is an input in both sectors and it can move freely from one sector to the other. All factors are fully employed.

The impact on the Japanese economy of the Meiji restauration, which opened the country to international trade can be illustrated with the aid of the diagram in figure 1 . The quantity of labor employed in the Kanto sector is measured on the horizontal axis $\mathrm{O}_{K a} \mathrm{O}_{k i}$, from $O_{K a}$ rightward, while labor used in Kinai goods production is measured from $O_{K i}$ leftward. The income from labor is the wage rate (denoted by $W$ ), measured on the vertical axes. The return of specific factors' owners is the rental rate ( $r$ for human capital, $R$ for land). In equilibrium, the following relations hold:

$p_{K a} M P_{l}^{K a}=p_{K i} M P_{l}^{K i}=w$

$p_{K a} M P_{H}^{K a}=r$

$p_{K i} M P_{T}^{K i}=R$

where:

$M P_{H}^{K a}, M P_{T}^{K i}=$ the marginal physical product of specific factors, human capital and land (terrain) respectively;

$M P_{l}^{K a}, M P_{l}^{K i}=$ the marginal physical product of the mobile factor, labor, in the Kanto respectively Kinai sector;

$w=$ marginal revenue product of labor;

$p_{K a}, p_{K i}=$ the price of Kanto goods and Kinai goods respectively.

In the initial autarchy state, the domestic price of the two goods was lower than abroad. The equilibrium was disturbed by the country's openness to international trade, which increased competition on the domestic market, chiefly in the import-competing Kinai. Admittedly, the increasing competitive pressure had ambiguous influence on the price of Kinai goods (it either did not change or dropped), the price of the Kanto goods most likely rose because upon entering free trade, Japan's export industries faced higher world prices. 
Therefore, the price of the Kanto goods rose and so did the marginal revenue product of labor in the respective sector, according to equation (5). On the diagram in figure 2 (appendix 1), this is illustrated by the upward shift of the $(\lambda)$ curve. In point $J, w$ (the marginal revenue product of labor) is higher than in point $E_{1}$. Yet $J$ cannot be an equilibrium point because it corresponds to a lower wage in Kinai relative to Kanto. It followed a migration of workers (a shift of labor) from Kinai toward Kanto. The amount of labor used in the former diminished by the measure of the $H H^{\prime}$ segment, adding to the latter. One can notice that the wage rate level in $E_{1}$ was lower than in $J$, the Japanese economy having moved from $J$ to $E_{1}$ along the $\left(\lambda_{1}\right)$ curve.

In the new equilibrium, the nominal wage rate was higher than in autarchy. However, the movement

of labor from Kinai to Kanto raised the marginal product of labor in the former sector (because the ratio $L / T$ dropped) and declined it in the latter (the ratio $L / H$ rose). Consequently, the real wage rate dropped in Kanto and rose in Kinai. The surplus of labor in Kanto, in parallel with a decline in the real wage rate allowed producers in Kanto to increase production and exports of Kanto goods. Yet the influence on the real income of labor was not clear cut, but depended on Japanese workers' consumption preferences, given that the Kanto goods were more expensive, while the Kinai goods were cheaper, than in autarchy.

The rise in the price of Kanto goods influenced the income of the specific factors differently. The labor shift from Kinai to Kanto lowered the ratio of human capital to labor $(H / L)$, thereby raising the marginal product of human capital in Kanto. As a result, the real price of human capital rose in terms of the ability to purchase both goods, which means the rise in the price of the Kanto goods made the owners of human capital stock in Kanto better off. At the same time, the labor shift from Kinai to Kanto raised the ratio of land to labor $(T / L)$, thereby declining the marginal product of land in Kinai As a result, the real price of land dropped, which means the rise in the price of the Kanto goods made the landlords in Kanto worse off: their real income fell in terms of the ability to purchase both goods.

\section{Japan's post WW II development period: factor specificity once again}

Heller (1976) used a similar procedure as the one used by Leontief (1956), expressing the factor proportion of a set of Japanese export goods of a given value by means of two ratios, that is: the amount of physical capital per total number of workers respectively the number of trained workers per total number of workers. The results clearly confirm that changes of factor proportion within the Japanese economy after the Meiji restauration, essentially modified the structure of the country's comparative advantage, reflected in a shift of Japanese exports form labor intensive goods toward the ones that use physical capital (machinery) and human capital (skills and knowhow) intensively. More specifically, the cited author further shows, if immediately after the war the Japanese exports had a pronounced duality (capital intensive goods were mostly sold to developing countries, whereas exports bound to western countries were preponderantly labor intensive), within 15 years (1955-1970) the two flows converged: in the late 1960s all 
Japanese exports, regardless of their destination, were intensive in physical and human capital. ${ }^{6}$

The 1970s Heller's test was less intriguing than had been Leontief's two decades before. However, the idiosyncratic duality of post-war exports, emphasized by Heller, renders factor intensity misleading in explaining Japan's international specialization after WW II. In fact, Japan's exports to developing countries were not properly labor intensive, as Heller contends, but rather human capital intensive. Had they been purely labor intensive in the quantitative sense of the word, the odds that Japan become a top industrial power in the $20^{\text {th }}$ century would have been poor. The truth is, despite low labor costs, Japan's unprecedented high growth rate during the Meiji era was primarily due to its "culture, closely observed social hierarchies and religious/spiritual values that adapted well to new industries and corporate structures." The most valuable heritage from the anteMeiji regime was the "jutsu", a generic term for "specialized human skill which enables one to perform remarkable feats". ${ }^{8}$ Thus, the specificity of human capital to Kanto goods production, I discussed earlier, stays. In addition, Japan's industrialization enjoyed large governmental support. "Because private entrepreneurs were reluctant to invest in risky capital-intensive new ventures, the government built industrial enterprises and operated them until they were firmly established. At that point, the state sold the ventures to politically favored commercial interests at fire-sale prices. The policy was corrupt, but it did serve to jumpstart key industries through direct government investment." 9 Obviously, the lavish governmental support helped the Japanese industries to become increasingly endowed with physical capital, thereby glowing capital intensive. This confirms Heller's conclusion, quoted earlier, that "in the late 1960s all Japanese exports, regardless of their destination, were intensive in physical and human capital."

What could one say about Kinai, namely the sector to which land was a specific factor? One could still presume that labor continued to move freely between sectors, further raising the nominal wage rate $(w)$ as well as capital owners' nominal income $(r)$ but lowering landlords' nominal income $(R)$. As a result, Kanto underwent a formidable growth in production and exports, whereas Kinai kept on declining, being fully dependent on governments' aid to survive. It is than no surprise that during the post-WW II period, Japan has been pursuing a draconian protectionism in the agricultural domain, as data in tables 1 and 2 (appendix 2) clearly show. Japan is a high-income country, yet its trade policy in agriculture strikingly differs from other rich countries' like United States, Canada and even European Union (the latter's agricultural protectionism being notorious). Japan's trade policy is closer to the developing countries' such as India, Vietnam or Morocco. Yet interestingly, whereas ad valorem tariffs on imported grain like rice and wheat are astronomical (862.4 percent respectively 184.6 percent, as per data in table 2, appendix 2 ), textile imports are moderately protected (7.1 percent, table 2 , appendix 2 ). In the textiles field, Japan's tariff protection is much closer to the developed countries group (about 7-8 percent, table 2, appendix 2) and considerably lower than developing countries' (between 25 and 40 percent, table 3, appendix 2). This is additional evidence that textiles are not labor intensive. 
$\underline{\text { Notes }}$

1. The goods were selected from sections $5,6,7$ and 8 of the SITC classification in 2 and 3 figures, and characterized by several qualities (quantified by coefficients taken from the US economy, considered as standard) such as: the value capital per worker; the skills ratio (the percentage of skilled workers in total workers), wages per worker, economies of scale, goods consumption ratio (percentage of goods produced respectively imported, bought by end-consumers), the date of first sale (goods' novelty), product differentiation. Economies of scale are designated by the exponent of the regression $v=k n^{\alpha}$, where $v$ is the ratio between the value added by firms employing $n$ workers and the average value added in the US industry. (Hufbauer, the cited article)

2. Louis Frédéric, Japan Encyclopedia, Harvard University Press, 2002, p. 624 https://books.google.ro/books?id=p2QnPijAEmEC\&pg=PA624\&redir_esc=y\#v=onepage\&q\&f=false

3. The Japanese companies have developed technologies capable to produce knowledge intensive products that are in great demand on global markets. Some of them are unique suppliers of certain industrial products or inputs. Japan Steel Works for example, is the only company in the world that has the technology to forge solid-steel vessels (to contain radioactivity) required by nuclear reactors. (JJapan's technology champions", The Economist, Nov.15 2009)

4. I constructed the production box after a model from K. Lancaster, "The Heckscher-Ohlin Model: A Geometric Treatment” (J. Bhagwati ed., International Trade: Selected Readings, Baltimore Penguin, 1969, p. 49)

5. In developing the model, I drew on Markusen, J.R., J.R.Melvin, W.H. Kaempfer, K.E. Maskus, International Trade, McGraw-Hill, Inc, 1995, pp. 126-129

6. The ratios were calculated considering the technology that was predominant in Japan in three different years: 1955, 1960 and 1970. According to Heller's measurements during 1955-1968 the Japanese exports' intensiveness in physical capital rose from $\$ 1.734$ (based on the technology of 1955) to $\$ 4.826$ (based on the technology of 1970), while skill intensiveness rose from 1.46 percent (based on the technology of 1955) to 4.38 percent (based on the technology of 1970). (Heller, 1976)

7. "From Jutsu Empiricism to Kansei Technology: Textile Manufacture in Japan from the Tokugawa period to the present"

8. www.usu.se/?fid=5001

9. Oxford Encyclopedia of the Modern World; a brief look at Japanese economic growth since 1964 from the April 2014 OECD Observer, https://international.uiowa.edu/sites/international.uiowa.edu/files/file uploads/japan in tokugawa period an d modernity.pdf

\section{References}

Balassa, B., 1986, Comparative Advantage in Manufactured Goods: A Reappraisal, The Review of Economics and Statistics, Vol. 68, No. 2, pp. 315-319

Bernhofen, D.M., Brown, J.C., Masuyaki, T., 2012, A direct test of the Stolper-Samuelson theorem: the natural experiment of Japan,

https://pdfs.semanticscholar.org/2d6f/ab88f27fc8a53669d735145b70297f2fefba.pdf

Harrigan J., 2003, Specialization and the Volume of Trade: Do the Data Obey the Laws?', in Handbook of International Trade, Blackwell Publishing Co., p.87

Hufbauer, G.C., 1970, The Impact of National Characteristics \& Technology on the Commodity Composition of Trade in Manufactured Goods, in The Technology Factor in International Trade, R. Vernon (ed.) NBER, pp.146-231

Jones, R.W., 1971, A Three-Factor Model in Theory, Trade, and History, in Trade, Balance of Payments and Growth, J. Bhagwati, ed., North-Holland Publishing Co.

Lancaster, K., 1969, The Heckscher-Ohlin Model: A Geometric Treatment in J. Bhagwati ed., International Trade: Selected Readings, Baltimore Penguin, 1969 
Leontief, W.W., 1956, Factor Proportions and the Structure of American Trade: Further Theoretical and Empirical Analysis, The Review of Economics and Statistics, Vol. 38, No. 4, pp. 386407

Markusen, J.R., Melvin, J.R., Kaempfer, W.H., Maskus, K.E., 1995, International Trade, McGraw-Hill, Inc.

Minhas, B.S., 1962, The Homohypallagic Production Function, Factor-Intensity Reversals, and the Heckscher-Ohlin Theorem, Journal of Political Economy, Vol. 70, No. 2, pp. 138-39, 143-44

Stolper, W. F., Samuelson, P.A., 1941, Protection and Real Wages, The Review of Economic Studies 9/1, pp. 58-73

\section{Appendix 1}

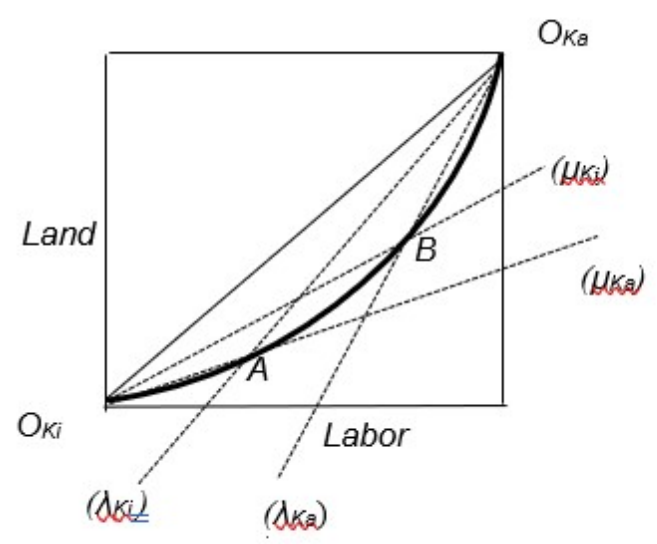

Figure 1 Japan's economy during the Meiji era (production box)

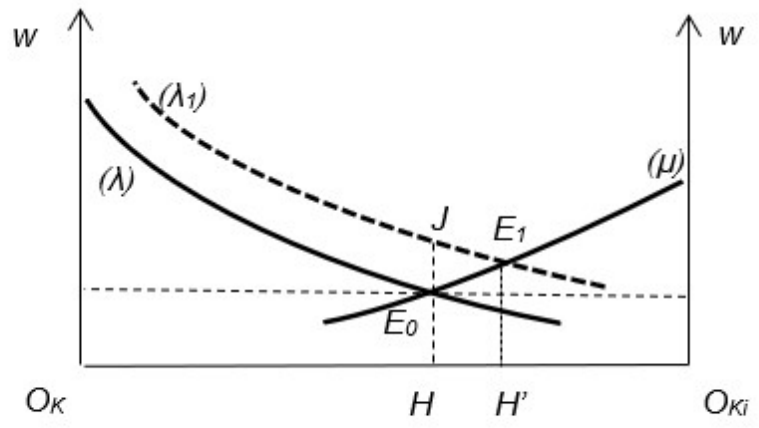

Figure 2 Japan's economy during the Meiji era (specific factor model) 


\section{Appendix 2}

Table 1 Import-weighted average applied tariffs, by sector and country, 2005 (percent)

\begin{tabular}{|c|c|c|c|c|c|}
\hline Importing region & $\begin{array}{r}\text { Agriculture, } \\
\text { processed } \\
\text { food, }\end{array}$ & $\begin{array}{r}\text { Primary } \\
\text { agriculture } \\
\text { only }\end{array}$ & $\begin{array}{l}\text { Processed } \\
\text { food only }\end{array}$ & $\begin{array}{l}\text { Textiles } \\
\text { clothing }\end{array}$ & $\begin{array}{r}\text { Other } \\
\text { manufac- } \\
\text { turing }\end{array}$ \\
\hline $\begin{array}{l}\text { High-income } \\
\text { Australia and New Zealand } \\
\text { EU } 25 \text { and EFTA } \\
\text { United States } \\
\text { Canada } \\
\text { Japan } \\
\text { Korea Rep. and Taiwan }\end{array}$ & $\begin{array}{r}2.6 \\
13.9 \\
2.4 \\
9.0 \\
29.3 \\
53.0\end{array}$ & $\begin{array}{r}0.3 \\
13.2 \\
2.3 \\
1.2 \\
48.0 \\
84.5\end{array}$ & $\begin{array}{r}3.3 \\
14.7 \\
2.5 \\
14.1 \\
20.8 \\
22.4\end{array}$ & $\begin{array}{r}13.9 \\
5.1 \\
9.6 \\
8.7 \\
9.0 \\
9.2\end{array}$ & $\begin{array}{l}4.1 \\
1.7 \\
0.9 \\
0.5 \\
0.4 \\
3.6\end{array}$ \\
\hline $\begin{array}{l}\text { Low-income } \\
\text { India } \\
\text { Vietnam }\end{array}$ & $\begin{array}{l}49.9 \\
37.1\end{array}$ & $\begin{array}{l}25.7 \\
13.1\end{array}$ & $\begin{array}{l}75.6 \\
44.8\end{array}$ & $\begin{array}{l}26.5 \\
29.1\end{array}$ & $\begin{array}{l}24.2 \\
12.3\end{array}$ \\
\hline
\end{tabular}

Source: Agricultural Trade Reform \& The Doha Development Agenda, edited by K. Anderson and W. Martin, Palgrave Macmillan and The World Bank, 2006, p. 345

Table 2 Applied tariffs by sector for selected importing regions, 2001

\begin{tabular}{|c|c|c|c|c|c|}
\hline $\begin{array}{l}\text { Trading sector } \\
\text { (Global Trade Analysis Project) }\end{array}$ & European & Japan & $\begin{array}{l}\text { United } \\
\text { States }\end{array}$ & $\begin{array}{l}\text { Korea } \\
\text { Rep. and } \\
\text { Taiwan }\end{array}$ & $\begin{array}{l}\text { Canada, } \\
\text { Australia, } \\
\text { New } \\
\text { Zealand }\end{array}$ \\
\hline $\begin{array}{l}\text { Agriculture and Food } \\
\text { Rice } \\
\text { Wheat } \\
\text { Other grains } \\
\text { Dairy products }\end{array}$ & $\begin{array}{l}92.6 \\
10.3 \\
21.3 \\
42.1\end{array}$ & $\begin{array}{r}862.4 \\
184.6 \\
39.0 \\
53.7\end{array}$ & $\begin{array}{r}4.4 \\
0.2 \\
0.0 \\
18.3\end{array}$ & $\begin{array}{r}874.8 \\
3.4 \\
258.0 \\
23.0\end{array}$ & $\begin{array}{r}0.0 \\
0.4 \\
0.0 \\
64.3\end{array}$ \\
\hline $\begin{array}{l}\text { Manufacturing } \\
\text { Textiles }\end{array}$ & 4.6 & 7.1 & 7.9 & 8.7 & 7.1 \\
\hline
\end{tabular}

Source: Agricultural Trade Reform \& The Doha Development Agenda, edited by K. Anderson and W. Martin, Palgrave Macmillan and The World Bank, 2006, pp. 390-91

Table 3 Average import tariffs in developing countries in 2001 (percent, ad valorem equivalent)

\begin{tabular}{|l|r|r|r|}
\hline Importing region & Agriculture and food & $\begin{array}{r}\text { Textiles and } \\
\text { apparel }\end{array}$ & $\begin{array}{r}\text { Other } \\
\text { merchandise }\end{array}$ \\
\hline China & 9.6 & 9.6 & 5.5 \\
Indonesia & 5.0 & 7.9 & 4.4 \\
Vietnam & 36.6 & 28.8 & 12.2 \\
India & 50.1 & 26.6 & 25.4 \\
Bangladesh & 12.7 & 30.1 & 16.0 \\
Morocco & 29.4 & 38.7 & 15.3 \\
Other South African countries & 23.7 & 27.8 & 16.3 \\
& & & \\
\hline
\end{tabular}

Source: Agricultural Trade Reform \& The Doha Development Agenda, edited by K. Anderson and W. Martin,

Palgrave Macmillan and The World Bank, 2006, p. 45 